удК 336.71

\title{
ТЕОРЕТИКО-МЕТОДИЧНІ ПІДХОДИ ЩОДО ДЕФІНІЦІї «ФІНАНСОВОГО ПОСЕРЕДНИЦТВА» ТА ФОРМАЛІЗАЦІЯ ЙОГО ВИДІВ
}

\section{THEORETICAL AND METHODOLOGICAL APPROACHES TO THE DEFINITION OF "FINANCIAL INTERMEDIATION" AND FORMALIZATION OF ITS TYPES}

\author{
Савченко Тарас Григорович \\ доктор економічних наук, профресор, \\ Сумський державний університет \\ ORCID: https://orcid.org/0000-0002-5001-609X \\ Серпенінова Юлія Сергіївна \\ кандидат економічних наук, доцент, \\ Сумський державний університет \\ ORCID: https://orcid.org/0000-0002-4448-3484 \\ Ярошина Аліна Павлівна \\ аспірант, \\ Сумський державний університет \\ ORCID: https://orcid.org/0000-0002-8694-4592
}

\author{
Savchenko Taras, Serpeninova Yuliia, Yaroshyna Alina \\ Sumy State University
}

\begin{abstract}
Стаття присвячена фрормалізації категоріального апарату таких суб'єктів економіки, як фрінансові посередники. Доведено проблематику інтерпретації даного поняття у зв'язку з відсутністю уніфікованого визначення терміну серед вітчизняних та закордонних науковців, а також у нормативних документах України. Проведено аналіз, синтез, систематизацію, узагальнення та порівняння підходів зарубіжних та вітчизняних авторів щодо сутності, визначення та видів фрінансових посередників. Зокрема, виокремлено інструментальний, інституціональний, фрункціональний та сутнісний підходи щодо визначення досліджуваного поняття. Авторами узагальнено, що більшість науковців підтримують функціональний та сутнісний підходи. Критичний аналіз наукової літератури дозволив здійснити авторську формалізацію класифрікаційних ознак фрінансових посередників за такими напрямками: приналежність до сектору економіки, види фрінансових послуг та діяльності, географія, форма акумулювання фрондів.
\end{abstract}

Ключові слова: фрінансові посередники, інвестиційна діяльність, банківський сектор, кредитування.

Статья посвящена фрормализации категориального аппарата таких субъектов экономики, как фринансовые посредники. Доказано проблематику интерпретации данного понятия в связи с отсутствием унифицированного определения среди отечественных и зарубежных ученых, а также в нормативных документах Украины. Проведен анализ, синтез, систематизация, обобщение и сравнение подходов зарубежных и отечественных авторов касательно сущности, определение и видов фринансовых посредников. В частности, выделены инструментальный, институциональный, функциональный и сущностный подходы к определению исследуемого понятия. Авторами обобщено то, что большинство ученых поддерживают фрункциональный и сущностный подходы. Критический анализ научной литературы позволил осуществить авторскую фрормализацию классифрикационных признаков фринансовых посредников по следующим направлениям: принадлежность к сектору экономики, виды фринансовых услуг и деятельности, география, фрорма аккумулирования фрондов.

Ключевые слова: финансовые посредники, инвестиционная деятельность, банковский сектор, кредитование.

Financial intermediaries are key players in the financial services market and ensure the efficient redistribution of financial resources. The development of such institutions contributes to the improvement of the country's investment portfolio, stimulates the attraction of free funds, has a positive effect on macroeconomic indicators of the economy. 
Different aspects of financial intermediation are of interest to both practitioners and are the center of scientific interest of many researchers. However, the lack of a unified approach to the definition of "financial intermediation" both in academia and in current legislation leads to ambiguous interpretation of this category and its personification depending on the needs of research and analysis. The lack of a single classification of types of financial intermediaries complicates a comprehensive understanding of the concept under study and necessitates further development of theoretical and methodological approaches. The article is devoted to the formalization of the categorical apparatus of such economic entities as financial intermediaries. The problematic interpretation of this concept is proved by the lack of a single definition of the term among domestic and foreign scholars, as well as in the regulations of Ukraine. The analysis, synthesis, systematization, generalization and comparison of approaches of foreign and domestic authors concerning the essence, definition and types of financial intermediaries are carried out. In particular, the author highlights the instrumental, institutional, functional and essential approaches to defining the concept being studied. It is generalized that most scientists support functional and substantive approaches. Critical analysis of the scientific literature made it possible to carry out the author's formalization of the classification features of financial intermediaries in the following areas: belonging to the economic sector, types of financial services and activities, geography, form of accumulation of funds. The aim of the article is to review the literature in order to summarize the existing approaches to the nature and types of financial intermediation in order to formalize the classification criteria by which financial intermediaries are divided into types.

Keywords: financial intermediaries, investment activities, banking sector, lending.

Постановка проблеми. Фінансові посередники є ключовими учасниками на ринку фрінансових послуг і забезпечують едективний перерозподіл фрінансових ресурсів. Різні аспекти фрінансового посередництва викликають інтерес як зі сторони практиків, так і $€$ фрокусом наукових інтересів багатьох дослідників. Так, теоретико-методичні підходи до вивчення категоріального апарату орінансового посередництва $€$ досить дискусійними. Зокрема, відсутність єдиного підходу стосовно визначення поняття «фрінансового посередництва» як у наукових колах, так і в чинному законодавстві призводить до неоднозначного трактування даної категорії та її персоніфікацію залежно від потреб дослідження та аналізу. Відсутність уніфрікованої класифрікації видів фрінансових посередників ускладнює комплексне розуміння досліджуваного поняття та обумовлює потребу подальшого розвитку теоретико-методичних підходів до визначення та фрормалізації видів фрінансових посередників.

Аналіз останніх досліджень і публікацій. Теоретико-методичні питання фрінансового посередництва досить активно досліджуються як у зарубіжних, так і у вітчизняних наукових колах. Зокрема, Редіш А. [1] свою роботу присвятила вивченню еволюції фрінансових посередників. Взаємозв'язок між діяльністю банків та фрінансових посередників розглянуто Заподеану Д. та Попа Д. [2]. Франклін А. [7] проводив дослідження місця посередників у банківському секторі. Голіков Д. [9] розглядав діяльність фрінансових посередників у контексті монетарної економіки. Проблему ролі підіймала у своїх роботах Левінсон Ч. [25].
Не можна не відмітити великий вклад у вивчення даної теми таких вітчизняних науковців, як Школьник І.О. [12], Волощенко Л.М. [13], Помогаева Е.А. [14], Доценко І.О. і Думарецької К.В. [15], Ткаченко Н.В. [16].

Формулювання цілей статті (постановка завдання). Ціллю статті $\epsilon$ огляд літератури 3 метою узагальнення існуючих підходів щодо сутності та видів фрінансового посередництва з метою фрормалізації класифрікаційних ознак, за якими фрінансові посередники поділяються на види.

Виклад основного матеріалу дослідження. Фінансові посередники відіграють важливу роль у процесі акумулювання грошових потоків. Розвиток діяльності таких установ сприяє покращенню інвестиційного порторелю країни, стимулює залучення вільних фондів. На сучасному етапі економіка України знаходиться на стадії відновлення та потребує великої кількості інвестицій, що прямо пов'язано 3 діяльністю фрінансових посередників.

У зарубіжній літературі існує досить багато визначень даної економічної категорії, зокрема Лівіо Ді Маттео [1] у своїй науковій праці дає таку дефрініцію: «Фінансове посередництво - це інструмент, який використовують фрінансової установи для розподілу коштів між позичальниками та кредиторами». Заподенуа Д. та Попа Д. [2] акцентують увагу на тому, що фрінансовий посередник це організація, яка виступає сполучною ланкою між інвестором та позичальником для досягнення фрінансових цілей обох сторін. У науковій роботі Майова A. [3] у визначенні терміну 3'являється формулювання, про роль ефективного розміщення коштів. 
Боссоне Б. [4] робив висунув ряд доказів, на користь того, що банки - це фрінансові посередники, проте фрінансові посередники не є банки. Це пояснюється тим, що поняття фрінансового посередництва $€$ більш ширшим і загальним та включає в себе багато інших інститутів.

Чен Дж. [5] у своїй роботі присвяченій темі фрінансового посередництва вводить у визначення термін «суб'єкт господарювання», який виступає середньою ланкою між сторонами фрінансової операції. Автор наголошує на тому, що даний інститут має багато переваг для користувачів його послуг, таких як: безпека, ліквідність та економія за рахунок масштабу. У свою чергу фрінансові посередники виступають каталізатором створення ефективних ринків та сприяють зниженню вартості ведення бізнесу. Через посередника суб'єкти, які мають надлишкові кошти об'єднуються у фонди, цим самим це дозволяє інвестувати більшу кількість активів.

Велику роль та важливість фрінансового посередництва доводили і Гортон Г. і Вінтон Е. [6]. Автори стверджували, що це центральний інститут розвитку економіки. Тоді як Франклін А. [7] навпаки доводив думку, що існування фонансових посередників можна ігнорувати, тому що вони не мають реального ефекту, не впливають на ціни активів або розподіл ресурсів.

Тобіас А. та Хен Сон Шін [8] тестували гіпотезу, що сектор фрінансових посередників $€$ двигуном, який керує фрінансовим циклом через коливання ціни ризику. У цьому контексті обсяги балансу виступають, як ключовий індикатор схильності до ризику, а отже, і як «канал прийняття ризиків» монетарної політики. Їх результати свідчать про те, що короткострокові процентні ставки мають важливе значення для впливу на розмір балансів срінансових посередників. Це $є$ підтвердженням ролі останніх у монетарній економіці.

Голіков Д. [9] під час трактування поняття «фрінансового посередництва» більше уваги приділяв його ролі, асаме двом фрундаментальним фрункціям: посередництво - об'єднання постачальників та користувачів капіталу без зміни характеру вимоги і об'єднання капіталу.

Організація економічного співробітництва та розвитку (OECD) у своєму глосарії подає таке визначення: «Фінансові посередники це одиниці, які несуть зобов'язання за власними рахунками на фрінансових ринках, через надання у позику фондів, які вони отримують на різних умовах іншими інституційними одиницями» [10].
Оксфордський словник бізнесу та управління дає наступне визначення: «Фінансовий посередник - це установа, будь то банк, будівельне товариство, фрінансовий будинок, страхова компанія, інвестиційний фронд тощо, яка зберігає кошти, позичені у кредиторів, для надання позик позичальникам» [11].

На думку вітчизняного науковця - Школьник І.О., «фрінансове посередництво» - це фрінансові установи, до яких належать суб'єкти банківської системи, небанківські фрінансові та кредитні інститути, контрактні фрінансові інститути [12].

Дещо відрізняється інтерпретація поняття подана Волощенко Л.М. [13]. Автор називає фрінансових посередників інститутами, фрункція яких полягає у акумулюванні коштів суб'єктів господарювання різних фрорм і наданні їх у володіння позичальників на комерційних засадах.

На противагу двом попереднім науковцям виступає Помогаева Е.А. У своїй роботі дослідниця дотримується думки, що це не інститут, і не установи, а діяльність, щодо ефрективного нагромадження, управління та перерозподілу капіталів. Це здійснюється шляхом надання фрінансових послуг, спільної діяльності фрінансових інститутів із забезпечення безперервності руху капіталу між економічними суб'єктами, що реалізується через подвійний обмін борговими вимогами і зобов'язаннями [14].

3 точки зору Доценко І.О. та Думарецької К.В. [15] сутність фрінансового посередництва полягає у залученні ресурсів для подальшого розміщення їх у фрінансові активи.

Сильно відрізняється від попередніх досліджень робота Ткаченко Н.В. [16]. Автор пропонує інтерпретувати орінансове посередництво одночасно і як процес, і як явище. Під процесом розуміється послідовність дій, які направлені на залучення вільних фрінансових ресурсів та розміщення їх у активи. А явище передбачає сукупність відносин, які супроводжують фрінансові послуги, метою яких є отримання позитивного результату - прибутку.

Ускладнює процес інтерпретації поняття відсутність уніфікованої дефрініції у нормативних документах України. Діяльність фрінансових посередників регулюється Законом України «Про фрінансові послуги та державне регулювання ринків фрінансових послуг» [17]. у документі поняття фрінансового посередництва не виділяється окремо, його ототожнюють 3 «фрінансовими установами», що $€$ досить широким підходом. Наступний нормативний акт, який тісно пов'язаний з діяльністю фрінансових посередників - це Закон України 
«Про інвестиційну діяльність» [18]. Однак зміст документа не в повній мірі стосується функціональної суті всіх видів посередників.

Дослідження даних інтерпретацій щодо визначення терміну «фрінансового посередництва» дає змогу виокремити декілька підходів. Такі автори, як Лівіо Ді Маттео [1] та Помогаева Е.А. [14] розглядають фрінансових посередників з точки зору інструментального підходу. Особлива увага у їх роботах приділяється ролі в економічному зростанні

Як один із інститутів економіки у своїх наукових роботах називали посередників такі автори як: Гортон Г., Вінтон Е. [6], Волощенко Л.М. [13] Вони розглядали поняття у більш широкому сенсі з огляду на масштаби впливу на економіку.

Функціональний підхід у інтерпретації поняття простежується у доробках Майова А. [3], Голікова Д. [9], Доценко І.О. [15], Думарецької К.В. [15], Ткаченко Н.В. [16]. Важливе місце у визначенні дефрініції автори приділяли ключовим ффункціям, які виконують посередники та робили їх конкретний перелік.

«Суб'єктом господарювання» або «економічною одиницею» визначали фрінансових посередників Чен Дж. [5], Заподенуа Д. [2], Попа Д. [2], Лоу Д. [11], Школьник І.О. [12]. Можна припустити, що даний підхід є наближеним до інституційного, проте відмінність полягає у масштабуванні.

Якщо розглянути склад авторів, які були включені нами до різних груп підходів, то не можна виокремити чіткого вектору думки для вітчизняних та зарубіжних представників. Це $€$ результатом того, що кожен із підходів включає, як українських, так і іноземних науковців.
Оскільки фрінансове посередництво це досить широке поняття, то дослідники поділяють його на різні види, беручи до уваги більш широкі або вужчі класифрікаційні ознаки. Так наприклад, Європейський центральний банк [19] виділяє два види: грошово-срінансові інститути та інші фрінансові посередники. Такий поділ $є$ найбільш широким та загальним.

Відмінною від попередньої $є$ класифрікація подана Раймондом В. [20] Автор наводить дві категорії - первинні та вторинні фрінансові посередники. Первині срінансові посередники - це ті, хто залучає кошти від домогосподарств, суб'єктів господарювання чи уряду та надає їх у свою чергу одним і тим же групам. Вторинні фрінансові посередники використовують власні кошти переважно для придбання цінних паперів або вимог до первинних фрінансових посередників.

Олександр П'єр Фор [21] поділяє фрінансових посередників на дві великі категорії: депозитні (банківський сектор) та не депозитні (інвестиційні механізми) (таблиця 1).

У свою чергу науковець виділяє ще одну окрему категорію - квазі фрінансові посередники. До їх переліку ввійшли: фрінансові інститути розвитку; короткострокові страхові агенти; інвестиційно-трастові компанії; інвестиційні компанії відкритого типу; фрінансові компанії; брокери-дилери цінних паперів; кредитні спілки; ощадні та кредитні кооперативи; купівельні асоціації; мікро-срінансові інститути [21].

Квазі фрінансові посередники - це установи, які не запозичають та/або не надають позик у тій же мірі, що й основні посередники, або не $є$ постійними кредиторами та пози-

Класифікація фрінансових посередників за спеціалізацією

Таблиця 1

\begin{tabular}{|l|c|}
\hline \multicolumn{1}{|c|}{ Депозитні фінансові посередники } & Не депозитні фінансові посередники \\
\hline 1. Центральний банк & 1. Договірні посередники \\
\hline 2. Комерційний банк & 1.1. Довгострокові страхові агенти \\
\hline 3. Інвестиційний банк & 1.2. Пенсійні фронди \\
\hline 4. Спеціалізовані та регіональні банки & 2. Колективні інвестиційні схеми \\
\hline 4.1. Взаємні банківські посередники & 2.1. Пайові інвестиційні фронди \\
\hline 4.1.1. Взаємні банки; & 2.2. Біржові фронди \\
\hline 4.1.2. Будівельні товариства; & 3. Альтернативні інвестиції \\
\hline 4.1.3. Позиково-ощадна асоціація; & 3.1. Хедж-фронди \\
\hline 4.1.4. Кооперативні банки & 3.2. Фонди приватного капіталу \\
\hline 4.2. Ощадні банки & \\
\hline 4.3. Регіональні сільські банки & \\
\hline 4.4. Ісламські банки & \\
\hline 5. Інші банківські інститути & \\
\hline
\end{tabular}

Джерело: складено авторами на основі [21] 
чальниками, тобто вони, як правило, мають фрінансові портфелі зобов'язань та активів, які мають тенденцію бути статичними [11].

Ключові характеристики, які відрізняють квазі фрінансових посередників від основних це те, що вони менші за обсягами трансакцій, вузько спеціалізовані та не залучають депозитів.

Дещо іншу класифрікацію у своїх роботах наводять: Прачі М. [22], Борад С. [23], Агарвал П. [24], Вайтсайд В. [25]. У вище названих джерелах зустрічається від 5 до 12 видів фрінансових посередників, їх можна узагальнити у такий перелік: банки; інвестиційні фонди; кредитні спілки; пенсійні фронди; страхові компанії; пайові фронди; фрондові біржі; розрахункові палати; фрінансові консультанти та брокери. Узагальнення та систематизація підходів щодо класифікації фрінансових посередників подано у таблиці 2.

Таким чином, на основі аналізу та систематизації існуючих підходів щодо класифрікації фрінансових посередників нами було узагальнено і фрормалізовано ознаки в єдину класифрікацію. Вони відрізняються між собою за суттю, фрункціями, фрормами акумулювання активів, масштабами, строковістю, видами діяльності.

На нашу думку, найбільш загальною та широкою $€$ класифрікація за приналежністю до певного сектору економіки. Так як більшість фрінансових посередників представлена у вигляді банків, то $€$ доцільним поділ на банківські та небанківські установи. Поділ за видами діяльності та фрінансових послуг $є$ досить схожими за представниками, проте відрізняється за суттю.
Остання класифрікаційна ознака включає первинних та вторинних посередників. Різниця полягає у тому, що перші залучають кошти та розміщують їх серед одних і тих самих груп суб'єктів (домогосподарств, юридичних осіб, уряду). У той час, як вторинні використовують власні кошти переважно для придбання цінних паперів.

Висновки і пропозиції. У ході дослідження нами було виділено основні групи підходів щодо трактування сутності поняття «фрінансове посередництво». Аналіз та систематизація трактувань зарубіжних та вітчизняних авторів свідчить про те, що більшість науковців схиляються до фрункціонального та сутнісного підходу. Найбільш загальним виявився інструментальний підхід, оскільки він зосереджений на ролі фрінансових посередників у економічному розвитку.

Систематизація наукових робіт, присвячених видам фрінансових посередників дало нам змогу виділити основні групи ознак, за якими можна здійснити класифрікацію даних суб'єктів, зокрема це: приналежність до сектору економіки, види фрінансових послуг та діяльності, регіональний критерій, срорма акумулювання фрондів.

Отримані в результаті проведеного дослідження результати узагальнюють існуючі підходи науковців у зарубіжної та вітчизняної наукової спільноти і можуть бути використані у якості теоретико-методичного підґрунтя для проведення подальших досліджень в окресленій тематиці.

\section{Авторська формалізація видів фрінансових посередників}

Таблиця 2

\begin{tabular}{|l|l|}
\hline \multicolumn{1}{|c|}{ Ознака } & \multicolumn{1}{c|}{ Види } \\
\hline $\begin{array}{l}\text { За приналежністю } \\
\text { до сектору економіки }\end{array}$ & $\begin{array}{l}\text { 1) Банківські (банки різних розмірів); } \\
\text { 2) Небанківські (кредитні спілки, ломбарди, довірчі товариства, } \\
\text { страхові та фрінансові компанії, інститути спільного інвестування, } \\
\text { недержавні пенсійні фонди); }\end{array}$ \\
\hline $\begin{array}{l}\text { За видами фрінансових } \\
\text { послуг }\end{array}$ & $\begin{array}{l}\text { 1) Депозитні інститути (комерційні банки, трастові фрірми, кредитні спілки); } \\
\text { 2) Контрактно-ощадні установи (страхові фрірми та пенсійні фронди); } \\
\text { 3) Інвестиційні посередники (інвестиційні фронди, іпотечні банки) }\end{array}$ \\
\hline За видами діяльності & $\begin{array}{l}\text { 1) Торгівля цінними паперами (брокери, дилери); } \\
\text { 2) Кредитування (банки, кредитні спілки); } \\
\text { 3) Інвестування (інвестиційні фонди, спілки); } \\
\text { 4) Страхування (страхові фрірми та пенсійні фонди) }\end{array}$ \\
\hline $\begin{array}{l}\text { За регіональним } \\
\text { охопленням }\end{array}$ & $\begin{array}{l}\text { 1) Місцеві; } \\
\text { 2) Регіональні; }\end{array}$ \\
\hline $\begin{array}{l}\text { 3) Загальнодержавні; } \\
\text { 4) Міжнародні }\end{array}$ \\
\hline акумулювовання фрондівв
\end{tabular}

Джерело: складено авторами на основі [20; 21; 23; 24; 25] 


\section{СПИСОК ВИКОРИСТАНИХ ДЖЕРЕЛ:}

1. Redish A. The evolution of financial intermediation: Evidence from 19th-century Ontario microdata. Canadian Journal of Economics. 2015. Vol. 48. Issue 3. P. 963-987.

2. Zapodeanu D., Popa D. The financial intermediaries, a real danger for banks? Annals of Faculty of Economics. 2008. Vol. 3. Issue 1. P. 901-904.

3. Mayowa A. Theory of financial intermediation. Financial markets and institutions. 2020. Vol. 2. Issue 2.

4. Bossone B. What Makes Banks Special? A Study of Banking, Finance, and Economic Development. Policy Research Working Paper. 2000. No 2408.

5. Chen J. Financial Intermediary. Investopedia. 2019. URL: investopedia.com

6. Gorton G., Winton A. Financial intermediation. NBER working paper series. 2002. No 8928.

7. Franklin A. Presidential Address: Do Financial Institutions Matter? Wharton Financial Institutions Center Working Paper. 2001. No. 01-04.

8. Adrian T., Shin H. Chapter 12 - Financial Intermediaries and Monetary Economics. Handbook of Monetary Economics. 2010. Vol. 3. P. 601-650.

9. Golikov D. Financial intermediary in monetary economics: an excerpt. Macroeconomics. 2005. URL: https://ideas.repec.org/p/wpa/wuwpma/0510018.html

10. The OECD Glossary of Statistical Terms. URL: https://stats.oecd.org/glossary/detail.asp?ID=970.

11. Law J. A Dictionary of Business and Management. Oxford University Press. 2009. http://doi:org/10.1093/ acref/9780199234899.001.0001

12. Школьник І.О. Фінансові посередники та їх роль у розвитку фінансового ринку. Проблеми і перспективи розвитку банківської системи. 2007. Вип. 22. С. 272-281.

13. Волощенко Л.М. Актуальні проблеми розвитку посередництва на фрінансовому ринку. Економічний простір. 2009. № 21. С. 199-205.

14.Помогаева Е.А. О модификации фрункций фринансовых посредников. Вісник ХГАЕП. 2010. № 1(46). С. 21-28.

15.Доценко І.О., Думарецька К.В. Сутність та роль фрінансових посередників на ринку фрінансових послуг України. Соціум. Наука. Культура. 2014. URL: http://intkonf.org/dotsenko-io-dumaretska-kv-sutnist-ta-rolfinansovih-poserednikiv-na-rinku-finansovih-poslug-ukrayini/

16. Ткаченко Н.В. Концепти сучасних уявлень про економічну природу фрінансового посередництва. Наукові записки Національного університету «Острозька академія». 2016. № 2(30). С. 103-108.

17.Про фрінансові послуги та державне регулювання ринків фінансових послуг : Закон України від 06.02.2003 № 2664-III. URL: https://zakon.rada.gov.ua/laws/show/2664-14\#Text

18. Про інвестиційну діяльність : Закон України від 18.09.1991 № 1560-XII. URL: https://zakon.rada.gov.ua/ laws/show/1560-12\#Text

19. European Central Bank. URL: https://www.ecb.europa.eu/mopo/eaec/intermediaries/html/index.en.html

20. Raymond W. Goldsmith. Financial Intermediaries in the American Economy since 1900. Princeton University Press. 1958. URL: https://www.nber.org/books-and-chapters/financial-intermediaries-american-economy-1900

21. Faure A. Financial Institutions: An introduction. $1^{\text {st }}$ edition. 2015.

22. Prachi M. Financial Intermediaries. The investors book. 2019. URL: https://theinvestorsbook.com/financialintermediaries.html

23. Borad S. Financial Intermediaries - Meaning, Functions, and Importance. Efinance Management. 2019. URL: https://efinancemanagement.com/sources-of-finance/financial-intermediaries

24. Agarwal P. Financial Intermediaries. Intelligent Economist. 2019. URL: intelligenteconomist.com

25. Whiteside E. 5 Types Of Financial Intermediaries. Top Accounting Degrees. 2019. URL: topaccountingdegrees.org

\section{REFERENCES:}

1. Redish, A. (2015) The evolution of financial intermediation: Evidence from 19th-century Ontario microdata. Canadian Journal of Economics, 48(3), 963-987. http://doi.org/10.1111/caje.12165

2. Zapodeanu, D., \& Popa, D. (2008) The financial intermediaries, a real danger for banks? Annals of Faculty of Economics, 3(1), 901-904. Retrieved from: https://www.researchgate.net/publication/46533400_THE_FINANCIAL_ INTERMEDIARIES_A_REAL_DANGER_FOR_BANKS

3. Mayowa, A. (2020) Theory of financial intermediation. Financial markets and institutions, 2(2). http://doi.org/10.13140/RG.2.2.14727.83365

4. Bossone, B. (2000) What Makes Banks Special? A Study of Banking, Finance, and Economic Development. Policy Research Working Paper, 2408. Retrieved from: http://surl.li/aeevy 
5. Chen J. (2019) Financial Intermediary. Investopedia. Retrieved from: https://www.investopedia.com/terms/f/ financialintermediary.asp

6. Gorton, G. \& Winton, A. (2002) Financial intermediation. NBER working paper series, 8928. http://doi.org/10.3386/w8928

7. Franklin, A. (2001) Presidential Address: Do Financial Institutions Matter? Wharton Financial Institutions Center Working Paper, 01-04. Retrieved from: https://papers.ssrn.com/sol3/papers.cfm?abstract_id=259492

8. Adrian, T. \& Shin, H. (2010) Chapter 12 - Financial Intermediaries and Monetary Economics. Handbook of Monetary Economics. 3, 601-650. http://doi.org/10.1016/B978-0-444-53238-1.00012-0

9. Golikov, D. (2005) Financial intermediary in monetary economics: an excerpt. Macroeconomics. Retrieved from: https://ideas.repec.org/p/wpa/wuwpma/0510018.html

10. The OECD Glossary of Statistical Terms. Retrieved from: https://stats.oecd.org/glossary/detail.asp?ID=970

11. Law, J. (2009) A Dictionary of Business and Management. Oxford University Press. http://doi.org/10.1093/ acref/9780199234899.001.0001

12. Shkolnyk I. (2007) Finansovi poserednyky ta yikh rol u rozvytku finansovoho rynku [Financial intermediaries and their role in the development of the financial market]. Problemy i perspektyvy rozvytku bankivskoi systemy Ukrainy - Problems and prospects of development of the banking system of Ukraine, 22, 272-281. Retrieved from: https://essuir.sumdu.edu.ua/bitstream-download/123456789/54828/5/Shkolnyk_Finansovi_poserednyky.pdf

13. Voloshchenko, L. (2009) Aktualni problemy rozvytku poserednytstva na finansovomu rynku [Current problems of financial intermediation development in the financial market]. Ekonomichnyi prostir - Economic space, 21, 199-205.

14. Pomohaeva, E. (2010) Modyfikatsii funktsii finansovoho poserednytstva [Modifications of financial intermediation functions]. Visnyk KhHAEP - Bulletin of the KhGAEP, 1(46), 21-28. Retrieved from: https://cyberleninka.ru/ article/n/o-modifikatsii-funktsiy-finansovyh-posrednikov/viewer

15. Dotsenko, I. \& Dumaretska, K. (2014). Sutnist ta rol finansovykh poserednykiv na rynku finansovykh posluh Ukrainy [Essence and role of financial intermediaries in the market of financial services of Ukraine]. Sotsium. Nauka. Kultura - Society. Science. Culture. Retrieved from: http://intkonf.org/dotsenko-io-dumaretska-kv-sutnist-ta-rol-finansovih-poserednikiv-na-rinku-finansovih-poslug-ukrayini/

16. Tkachenko, N. (2016) Kontsepty suchasnykh uiavlen pro ekonomichnu pryrodu finansovoho poserednytstva [Concepts of modern ideas about the economic nature of financial intermediation]. Naukovi zapysky Natsionalnoho universytetu «Ostrozka akademiia - Scientific notes of the National University "Ostroh Academy, 2(30), 103-108. Retrieved from: http://nbuv.gov.ua/UJRN/Nznuoa_2016_2_20

17. Pro finansovi posluhy ta derzhavne rehuliuvannia rynkiv finansovykh posluh: Zakon Ukrainy vid 06.02.2003 № 2664-III [Pro finansovi posluhy ta derzhavne rehuliuvannia rynkiv finansovykh posluh: Zakon Ukrainy vid 06.02.2003 № 2664-III]. Retrieved from: https://zakon.rada.gov.ua/laws/show/2664-14\#Text

18. Pro investytsiinu diialnist: Zakon Ukrainy vid 18.09.1991 № 1560-XII [Pro investytsiinu diialnist: Zakon Ukrainy vid 18.09.1991. № 1560-XII]. Retrieved from: https://zakon.rada.gov.ua/laws/show/1560-12\#Text

19. European Central Bank. Retrieved from: https://www.ecb.europa.eu/mopo/eaec/intermediaries/html/index.en.html

20. Raymond, W. (1958) Financial Intermediaries in the American Economy since 1900. Princeton University

Press. Retrieved from: https://www.nber.org/books-and-chapters/financial-intermediaries-american-economy-1900

21. Faure, A. (2015) Financial Institutions: An introduction. 1st edition. Retrieved from: https://www.researchgate.net/ publication/273453091_Financial_Institutions_An_Introduction

22. Prachi, M. (2019) Financial Intermediaries. The investors book. Retrieved from: https://theinvestorsbook.com/ financial-intermediaries.html

23. Borad, S. (2019) Financial Intermediaries - Meaning, Functions, and Importance. Efinance Management. Retrieved from: https://efinancemanagement.com/sources-of-finance/financial-intermediaries

24. Agarwal, P. (2019) Financial Intermediaries. Intelligent Economist. Retrieved from: intelligenteconomist.com

25. Whiteside, E. (2019) 5 Types Of Financial Intermediaries. Top Accounting Degrees. Retrieved from: topaccountingdegrees.org 